\title{
Pengaruh Variasi Konsentrasi Montmorillonit Terhadap Sifat dan Kinerja Membran Kitosan/PVA/MMT Untuk Aplikasi DMFC
}

\author{
Shalahudin Nur Ayyubi', Lukman Admaja ${ }^{2}$ \\ Universitas Diponegoro ${ }^{1}$ \\ Institut Teknologi Sepuluh Nopember Surabaya ${ }^{2}$ \\ E-mail: shalahudinnurayyubi@gmail.com
}

\begin{abstract}
Abstrak
Sintesis membran komposit kitosan/PVA/MMT telah berhasil dilakukan dengan menggunakan metode inversi fasa. Pada penelitian ini, kitosan/polivinil alkohol sebagai matriks polimer, Kmontmorillonit (MMT) sebagai filler anorganik dengan asam sulfat sebagai agen pengikat silang. Tujuan penelitian ini adalah untuk mengetahui pengaruh variasi konsentrasi montmorilonit $(1$, 2, dan $4 \%$ ) terhadap sifat dan kinerja membran komposit. Hasil sintesis membran komposit telah dikonfirmasi dengan adanya serapan gugus fungsi yang khas pada FTIR. Modifikasi dengan polivinil alkohol (PVA) dan montmorillonit menunjukkan dapat memperbaiki sifat dan kinerja membran komposit. Peningkatan konsentrasi montmorillonit cenderung menaikkan water uptake dan methanol uptake. Membran CS/PVA/MMT 4\% merupakan membran yang menjanjikan dengan kinerja yang lebih baik daripada membran yang lain, dengan persentase water uptake yang tinggi dan methanol uptake rendah, selain itu memiliki nilai permeabilitas metanol yang sangat rendah yaitu $7,165 \times 10-8 \mathrm{~cm}^{2} / \mathrm{s}$.
\end{abstract}

Kata kunci: membran; kitosan; Direct Methanol Fuel Cell; sel bahan bakar; material komposit

\begin{abstract}
Chitosan / PVA / MMT composite membrane synthesis has been successfully carried out using the phase inversion method. In this study, chitosan/polyvinyl alcohol as a polymer matrix, $K$ montmorillonite (MMT) as an inorganic filler with sulfuric acid as a crosslinking agent. The purpose of this study was to study variations in the concentration of montmorillonite (1,2, and 4\%) on the properties and performance of composite membranes. The results of the composite membranes synthesis were confirmed by the presence of a unique functional group absorption in FTIR. Modifications with polyvinyl alcohol (PVA) and montmorillonite can improve the properties and performance of composite membranes. Increasing concentration of montmorillonite tends to increase water uptake and methanol uptake. The CS / PVA / MMT 4\% membrane is a promising membrane with better performance than other membranes, with high water absorption and low methanol absorption, besides it has a very low methanol permeability value of $7.165 \times 10-8 \mathrm{~cm}^{2} / \mathrm{s}$.
\end{abstract}

Keywords: membrane; chitosan; Direct Methanol Fuel Cell; fuel cell; composite material 


\section{Pendahuluan}

Harga bahan bakar fosil, khususnya minyak dan gas alam, telah meningkat tajam selama beberapa tahun terakhir. Oleh karena itu, perlu dilakukan penelitian-penelitian untuk menemukan alternatif baru penghasil energi. Namun di sisi lain, seiring dengan perkembangan teknologi, tuntutan untuk tetap menjaga lingkungan juga semakin meningkat.

Menurut Li, Xu, dan Wang (2003) DMFC (Direct Methanol Fuel Cell) dapat menjadi salah satu alternatif sebagai energi terbaharukan untuk mengatasi masalah krisis energi. DMFC merupakan sel bahan bakar dengan sumber bahan bakar berupa metanol. DMFC dapat menjadi sistem yang sangat menjanjikan dalam berbagai aspek karena mudah dimodifikasi, memiliki efisiensi yang tinggi, tidak memerlukan peralatan pengolahan bahan bakar, serta dapat beroperasi pada suhu rendah antara $40-120^{\circ} \mathrm{C}$ (Smitha, Sridhar and Khan, 2005).

Membran penghantar proton (elektrolit) adalah salah satu kunci dari komponen DMFC. Membran seperti itu digunakan untuk menyediakan jalur konduktif proton dan untuk memisahkan bahan bakar dan oksidan secara bersamaan kompartemen anoda dan katoda di sel bahan bakar. Polimer yang sering digunakan untuk membran elektrolit adalah perfluorinasi polimer berbasis ionomer yang dikenal dengan nama dagangnya, Nafion (Abu-Saied et al., 2020). Meskipun memiliki konduktivitas proton yang tinggi dan stabilitas kimia, elektrokimia dan mekanis pada suhu lingkungan (Ren, 1995), Nafion sangat sulit untuk disintesis dan diproses dan harganya juga tinggi serta permeabilitas metanol yang tinggi (Gurau and Smotkin, 2002; Barragán et al., 2004).

Sebagai alternatif, kitosan (CS) telah menarik perhatian besar karena kemampuan pembentukan film yang bagus, fungsionalisasi lebih mudah, biaya murah, permeabilitas metanol yang rendah, dan karakteristik ramah lingkungan (Ma and Sahai, 2013). Namun, kristalinitas yang tinggi, kurangnya proton bergerak dalam struktur kitosan, dan stabilitas mekanis yang buruk membatasi utilitasnya pada DMFC. Pengembangan membran komposit merupakan strategi utama untuk menambah rasio selektivitas permeabilitas konduktivitas-metanol ionik, dan soliditas termal membran kitosan (Vaghari et al., 2013; Liu et al., 2016).

Salah satu upaya meningkatkan kinerja membran kitosan adalah dengan memodifikasi kitosan menggunakan polivinil alkohol (PVA). Kelebihan PVA adalah memiliki harga murah, dapat meningkatkan konduktivitas proton, dan mampu beroperasi pada suhu tinggi yaitu $228^{\circ} \mathrm{C}$ $256^{\circ} \mathrm{C}$ (Kakati et al., 2015).

Selain itu montmorillonit menjadi kandidat yang cukup populer digunakan sebagai filler pada sintesis membran komposit karena memiliki beberapa keunggulan antara lain mudah didapat, memiliki luas permukaan spesifik yang besar, tahan bahan kimia, memiliki kemampuan absorpsi yang kuat, dan memiliki kapasitas tukar kation yang baik, serta memiliki kemampuan perekat yang baik (Liu, $\mathrm{Hu}$ and $\mathrm{Hu}, 2008$; Liu et al., 2011; Zhu et al., 2015). Tujuan penambahan filler anorganik terhadap matriks membran ini adalah untuk mendapatkan membran penukar proton ideal yang kriterianya adalah memiliki nilai konduktivitas proton yang relatif tinggi, mampu mempertahankan sifat kelembaban pada operasi suhu tinggi dan dapat menjaga keseimbangan sifat hidrofilik-hidrofobik pada membran komposit yang telah dimiliki secara alami (Tripathi and Shahi, 2011). Seperti yang telah dilaporkan oleh (Enggita and Santoso, 2015) membran komposit CS/PVA/MMT memiliki konduktifitas yang masih rendah dibandingkan Nafion. Kelebihan penambahan montmorillonit diharapkan mampu menambah sifat hidrofilik dari membran sehingga mampu meningkatkan konduktivitas proton. 


\begin{abstract}
Pada penelitian ini dilakukan pembuatan membran komposit kitosan/PVA/MMT dengan variasi konsentrasi MMT 1, 2, dan 4\% untuk mengetahui konsentrasi optimum montmorillonit. Sebelumnya pada penelitian (Junianto, 2017) menunjukkan bahwa nilai water uptake paling baik ditunjukkan pada membran CS/PVA/MMT 4\%.
\end{abstract}

\section{Metode Penelitian}

\section{Alat dan Bahan}

Peralatan yang digunakan dalam penelitian ini adalah peralatan kaca laboratorium pada umumnya, blender, timbangan analitik, piknometer, miling tools, pemanas elektrik, oven, termometer, indikator, $\mathrm{pH}$ universal, kain katun, magnetik stirer, ayakan, pengaduk, ultrasonic batch, plastic dish, dan satu set alat uji permeabilitas metanol. Membran komposit dikarakterisasi menggunakan instrumen FTIR (Fourier Transform Infra Red) (8400S Shimadzu).

Pada penelitian ini menggunakan bahan-bahan sebagai berikut: akuades (SAP Chemicals), kulit udang (Penaeus monodon), montmorilonit K-10 (Sigma-Aldrich), polivinil alkohol (Merck), pelet $\mathrm{NaOH}$ (Merck), larutan asam sulfat (SAP chemials), dan larutan asam asetat (SAP Chemicals).

\section{Prosedur Kerja}

\section{1) Ekstraksi Kitosan}

\section{Deproteinasi}

Kulit udang kering yang telah halus dicampur dengan $\mathrm{NaOH} 3,5 \%$ dengan perbandingan 1:10 (g serbuk/mL NaOH) pada suhu $65^{\circ} \mathrm{C}$ dengan menggunakan magnetik stirer dengan kecepatan $400 \mathrm{rpm}$ selama 2 jam. Campuran selanjutnya dipisahkan dengan cara disaring untuk memisahkan endapan dalam bentuk slurry, yang kemudian dicuci dengan akuades sampai netral pHnya. Endapan selanjutnya dioven pada suhu $105^{\circ} \mathrm{C}$ selama 4 jam sehingga diperoleh serbuk kering. Serbuk kering yang diperoleh ditimbang dan dihitung persentase hasilnya dari berat awal. Pada tahap akhir ini serbuk diuji dengan ninhidrin untuk mengetahui apakah masih ada kadar protein dalam hasil akhir serbuk.

\section{Demineralisasi}

Proses demineralisasi dilakukan pada suhu $65^{\circ} \mathrm{C}$ dengan menggunakan larutan $\mathrm{HCl} 1 \mathrm{M}$. Serbuk kering hasil deproteinasi dicampur dengan larutan $\mathrm{HCl}$ dengan perbandingan 1:15 (g serbuk/mL $\mathrm{HCl}$ ). Campuran diaduk selama 30 menit. Campuran setelah itu disaring untuk memisahkan endapan yang selanjutnya dinetralkan menggunakan akuades. Endapan kemudian dioven pada suhu $105^{\circ} \mathrm{C}$ selama 4 jam sehingga diperoleh serbuk kering kitin murni, yang selanjutnya diidentifikasi dengan FTIR untuk melihat puncak khas yang dihasilkan dari kitin.

\section{Deasetilasi}

Pada tahap ini kitin ditambahkan larutan $\mathrm{NaOH} 50 \%(\mathrm{~m} / \mathrm{v})$ dengan rasio 1:10 (m/v), selanjutnya dipanaskan dan diaduk pada suhu $120^{\circ} \mathrm{C}$ selama 4 jam. Slurry yang dihasilkan kemudian disaring serta dinetralkan pH-nya menggunakan akuades. Slurry selanjutnya dikeringkan dalam oven pada suhu $105^{\circ} \mathrm{C}$ selama 4 jam sehingga diperoleh serbuk kitosan murni yang tahap berikutnya dianalisis dengan FTIR (Purwanto et al., 2016).

\section{2) Sintesis membran kitosan}

Sebanyak 2 g kitosan dilarutkan menggunakan larutan asam asetat $2 \%(\mathrm{v} / \mathrm{v})$ dengan volume $75 \mathrm{~mL}$ dalam gelas beker kemudian diaduk dan dipanaskan pada suhu $80^{\circ} \mathrm{C}$ selama 30 menit. Selanjutnya larutan diultrasonik selama 30 menit. Campuran kemudian dituang dalam plastic dish dan dikeringkan pada suhu kamar hingga didapatkan membran kering. Selanjutnya membran dinetralkan menggunakan akuades dan kemudia membran dikeringkan pada suhu kamar (Umar, Permana and Atmaja, 2016). 
Tabel 1. Komposisi Membran (gram)

\begin{tabular}{cccc}
\hline Membran & $\begin{array}{c}\text { Massa } \\
\text { Kitosa } \\
\mathrm{n}\end{array}$ & $\begin{array}{c}\text { Mass } \\
\mathrm{a}\end{array}$ & $\begin{array}{c}\text { Massa } \\
\text { MMT }\end{array}$ \\
\hline CS & 2,005 & - & - \\
\hline CS/PVA & 0,5 & 1,5 & - \\
\hline $\begin{array}{c}\text { CS/PVA/MMT } \\
\text { 1\% }\end{array}$ & 0,5 & 1,5 & 0,02 \\
\hline $\begin{array}{c}\text { CS/PVA/MMT } \\
\text { 2\% }\end{array}$ & 0,5 & 1,5 & 0,04 \\
\hline $\begin{array}{c}\text { CS/PVA/MMT } \\
\text { 4\% }\end{array}$ & 0,5 & 1,5 & 0,08 \\
\hline
\end{tabular}

\section{3) Sintesis Membran Kitosan/PVA/MMT}

Membran

kitosan/PVA/MMT dibuat dengan

mendispersikan montmorilonit sebanyak 1 , 2, dan 4\% dari berat total kitosan dan PVA ke dalam akuades $20 \mathrm{~mL}$ dengan menggunakan magnetik stirer selama 30 menit dan di ultrasonik selama 30 menit (Umar, Permana and Atmaja, 2016). Variasi perbandingan massa kitosan/PVA dalam penelitian ini adalah 1:3.

Di gelas beker lain serbuk PVA dilarutkan dalam akuades sebanyak 4\% ( $\mathrm{m} / \mathrm{v})$ diaduk dan dipanaskan selama 2 jam pada suhu $70^{\circ} \mathrm{C}$ menghasilkan larutan PVA. Larutan montmorillonit kemudian ditambahkan ke dalam larutan PVA lalu diaduk dan dipanaskan selama 15 menit pada suhu $70^{\circ} \mathrm{C}$ hingga dihasilkan campuran PVA/MMT. Dalam gelas beker yang lain serbuk kitosan dilarutkan ke dalam asam.

Setelah itu, ke dalam campuran PVA/MMT ditambahkan larutan kitosan yang dilanjutkan dengan pengadukan selama 3 jam pada suhu $70^{\circ} \mathrm{C}$ (Enggita and Santoso, 2015). Campuran akhir dituang ke dalam cetakan dan dikeringkan pada suhu kamar selama kurang lebih 17 hari. Selanjutnya membran direndam dalam larutan asam sulfat $2 \mathrm{~N}$ selama 24 jam dan kemudian, membran dinetralkan menggunakan akuades. Selanjutnya, membran dikeringkan pada suhu kamar.

\section{4) Sintesis Membran Kitosan/PVA}

Larutan kitosan ditambahkan ke dalam larutan PVA yang telah homogen. Campuran dimasukkan ke dalam ultrasonic batch selama 30 menit. Kemudian diaduk pada suhu $70^{\circ} \mathrm{C}$ selama 3 jam. Larutan campuran dicetak dalam plastic dish, dibiarkan hingga kering selama 14 hari. Setelah kering diikat silang dengan larutan asam sulfat $2 \mathrm{~N}$ dibiarkan hingga kering. Kemudian dicuci dengan akuades dan dibiarkan kering kembali.

\section{Karakterisasi Menggunakan FTIR}

Membran yang akan dianalisa gugus fungsinya diambil dengan ketebalan $10-15$ $\mu \mathrm{m}$, kemudian dilakukan analisa pengukuran pada panjang gelombang antara $4000-400$ $\mathrm{cm}^{-1}$ (Lavorgna et al., 2010).

\section{Uji Water Uptake dan Methanol Uptake}

Pada uji Water uptake dan methanol uptake dilakukan dengan mengukur perbedaan berat membran sebelum dan sesudah direndam dalam air atau metanol. Berat basah $\left(\mathrm{W}_{\text {basah }}\right)$ diukur dari membran yang direndam pada air atau metanol $5 \mathrm{M}$, sedangkan berat kering ( $\mathrm{W}_{\text {kering }}$ ) diukur dari membran yang dikeringkan selama 24 jam pada suhu ruang. Untuk perhitungan water uptake dan methanol uptake digunakan persamaan berikut :

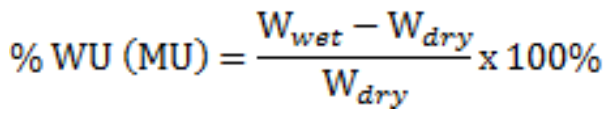

\section{Uji Permeabilitas Metanol}

Kompartemen A dan B masing masing diisi larutan metanol dan akuades, kemudian sampel yang berbentuk lingkaran ditempatkan di antara keduanya. Pada proses pengujian selanjutnya, setiap kompartemen yang berisi metanol dan akuades tersebut diaduk. Untuk pengujian permeabilitas metanol akan digunakan 
larutan metanol dengan konsentrasi $5 \mathrm{M}$. Setiap 20, 40, 60, 80, 100 menit, sisi kompartemen berisi akuades diambil sebanyak volume piknometer untuk mengetahui konsentrasi metanolnya melalui suatu teknik penggunaan piknometer. Nilai permeabilitas metanol diperoleh dengan menggunakan Persamaan :

Permeabilitas $=\frac{S V_{B} L}{A C_{A O}}$

$\mathrm{S}$ adalah slope pada grafik; VB (mL) adalah volume dari kompartemen $\mathrm{B}$ (akuades); $\mathrm{CA}_{0}(\mathrm{~mol} / \mathrm{L})$ adalah konsentrasi awal metanol dalam kompartemen A (metanol); L (cm) adalah ketebalan membran; dan A $\left(\mathrm{cm}^{2}\right)$ adalah luas area dari membran.

\section{Hasil Penelitian dan Pembahasan}

\section{Sintesis Kitosan}

Untuk memperoleh kitosan, langkah awalnya adalah proses deproteinasi. Pada proses deproteinasi, bertujuan untuk menghilangkan kandungan protein yang terdapat pada kulit udang dengan melarutkan kulit udang menggunakan basa lemah $\mathrm{NaOH} \mathrm{3,5 \% .} \mathrm{Metode} \mathrm{ini} \mathrm{merupakan}$ kondisi optimum untuk reaksi deproteinasi sehingga dapat terjadi pemutusan protein dan menjadi Na-proteinat yang dapat larut dalam air.

Tahap selanjutnya setelah perlakuan deproteinasi adalah proses demineralisasi untuk menghilangkan senyawa anorganik dengan cara menambahkan larutan HCL 1M. Pada kulit udang terdapat kandungan mineral terbanyak seperti $\mathrm{CaCO}_{3}$ dan adapula sedikit mineral berupa $\mathrm{Ca}_{3}\left(\mathrm{PO}_{4}\right)_{2}$. Reaksi yang terjadi adalah sebagai berikut:

$\mathrm{CaCO}_{3(\mathrm{~s})}+2 \mathrm{HCl}_{(\mathrm{aq})} \rightarrow \mathrm{CaCl}_{2(\mathrm{aq})}+\mathrm{H}_{2} \mathrm{O}_{(\mathrm{l})}+$ $\mathrm{CO}_{2(\mathrm{~g})} \mathrm{Ca}_{3}\left(\mathrm{PO}_{4}\right)_{2(\mathrm{~s})}+4 \mathrm{HCl}_{(\mathrm{aq})} \rightarrow 2 \mathrm{CaCl}_{2(\mathrm{aq})}+$ $\mathrm{Ca}\left(\mathrm{H}_{2} \mathrm{PO}_{4}\right)_{2(\mathrm{aq})}$

Tahapan akhir yang harus dilakukan untuk mendapatkan serbuk kitosan murni adalah proses deasetilasi. Dimana tahapan ini merupakan transformasi kitin menjadi kitosan melalui proses penghilangan gugus asetil $\left(-\mathrm{COCH}_{3}\right)$ dari kitin dengan menggunakan pereaksi basa kuat yakni $\mathrm{NaOH} 50 \%$ dengan konsentrasi tinggi agar berubah menjadi gugus amina $\left(-\mathrm{NH}_{2}\right)$. Berikut persen kehilangan berat massa selama proses isolasi kitosan dari berat awal 300 gram kulit udang. Hasil persen akhir keseluruhan dapat dilihat pada Tabel 2.

Tabel 2. Persentase kehilangan berat selama isolasi kitosan

\begin{tabular}{|l|l|c|c|}
\hline No & Proses & $\begin{array}{l}\text { Berat } \\
\text { (gram) }\end{array}$ & $\begin{array}{l}\text { \%Kehilangan } \\
\text { Berat }\end{array}$ \\
\hline 1 & Deproteinasi & 147,54 & $50,81 \%$ \\
\hline 2 & Demineralisasi & 84,605 & $42,66 \%$ \\
\hline 3 & Deasetilasi & 66,924 & $20,89 \%$ \\
\hline
\end{tabular}

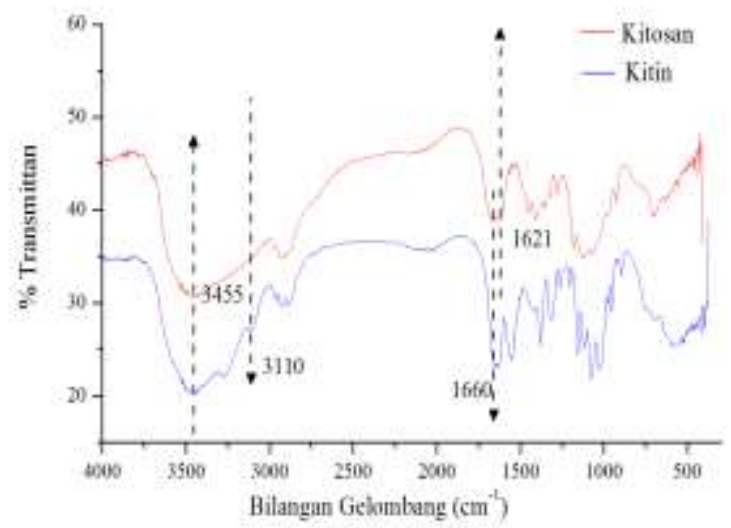

Gambar 1. Spektra FTIR kitosan dan kitin

Untuk memastikan kemurnian kitosan, maka perlu dilakukan beberapa parameter uji kualitatif maupun kuantitatif. Uji kualitatif dapat dilihat dari serapan gugus fungsi dari spektra FTIR kitosan, hal ini untuk membedakan pergeseran bilangan gelombang antara kitin dan kitosan. Sedangkan untuk uji kuantitatif yaitu ditentukan dari perhitungan derajat deasetilasi (DD) transformasi kitin dan kitosan. Gambar 1 di atas memperlihatkan hasil karakterisasi FTIR antara kitin dan kitosan. 
Secara umum serapan gugus fungsi IR pada kitosan dapat dilihat pada Tabel 3 .

Tabel 3. Jenis vibrasi gugus fungsi pada kitosan

\begin{tabular}{|c|c|c|}
\hline $\begin{array}{c}\text { Bilangan } \\
\text { Gelombang } \\
\left(\mathrm{cm}^{-1}\right)\end{array}$ & $\begin{array}{c}\text { Jenis } \\
\text { Vibrasi }\end{array}$ & $\begin{array}{c}\text { Gugus Yang } \\
\text { Bervibrasi }\end{array}$ \\
\hline $3000-3500$ & Regang & O-H dan N-H \\
\hline 2926 & Regang & $\mathrm{CH}, \mathrm{CH}_{3}$ \\
\hline 1621 & Regang & $\mathrm{C}=\mathrm{O}$ amida \\
\hline 1403 & Tekuk & $\mathrm{C}-\mathrm{H}$ \\
\hline 1159 & Regang & $\mathrm{C}-\mathrm{O}-\mathrm{C}$ \\
\hline
\end{tabular}

Keberhasilan terbentuknya gugus amina (kitosan) ini dapat ditentukan secara kuantitatif. Penentuan kuantitatif dilakukan dengan cara menghitung derajat deasetilasi kitosan. Menurut (Khan, Peh and Ch'ng, 2002) derajat deasetilasi kitosan yang dihasilkan mempengaruhi kualitas dan aplikasi kitosan di berbagai bidang. Kemudian hasil akhir diperoleh kitosan dengan derajat deasetilasi sebesar 74,45\%.

\section{Karakterisasi Membran Komposit CS/PVA/MMT Menggunakan FTIR}

Gambar 2 berikut menyajikan hasil spektra FTIR membran kitosan (CS) dan CS/PVA/MMT dengan konsentrasi montmorilonit sebesar 1 dan 4\%.

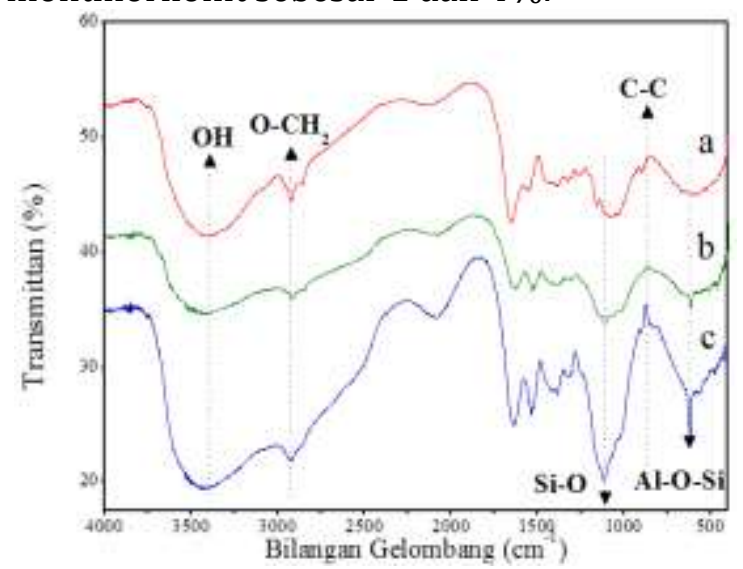

Gambar 2. Spektra FTIR Membran Kitosan (CS) (a), Membran CS/PVA/MMT 1\% (b), dan CS/PVA/MMT 4\% (c)

Dari data yang didapatkan di atas menunjukkan bahwa membran komposit
CS/PVA/MMT telah berhasil disintesis dilihat dari serapan gugus fungsi yang terbentuk merupakan gabungan dari spektrum unsur-unsur penyusun membran yaitu kitosan, polivinil alkohol, dan montmorillonit. Dari Gambar 2 pula dapat diperkirakan pengaruh konsentrasi montmorilonit pada membran CS/PVA/MMT, hal ini dapat dibuktikan dengan serapan FTIR yang semakin tajam seiring dengan bertambahnya konsentrasi montmorilonit pada daerah panjang gelombang $1107 \mathrm{~cm}^{-1}$ yaitu vibrasi gugus fungsi -Si-O dan $618 \mathrm{~cm}^{-1}$ vibrasi Al-O-Si.

\section{Uji Water Uptake dan Methanol Uptake}

Untuk mengetahui kemampuan membran untuk menyerap air atau metanol dilakukan uji water uptake dan methanol uptake. Hal ini dilakukan karena penyimpanan air atau metanol akan menentukan konduktivitas proton dan kinerja membran. Semakin tinggi nilai water uptake maka konduktivitas proton pada membran semakin baik, sebaliknya semakin tinggi nilai methanol uptake maka kinerja membran semakin buruk karena terlalu banyak metanol yang diserap menyebabkan cross-over pada sel bahan bakar, sehingga terjadi penurunan voltase pada sel bahan bakar. Berikut Gambar 3 menunjukkan nilai water uptake dan methanol uptake membran komposit.

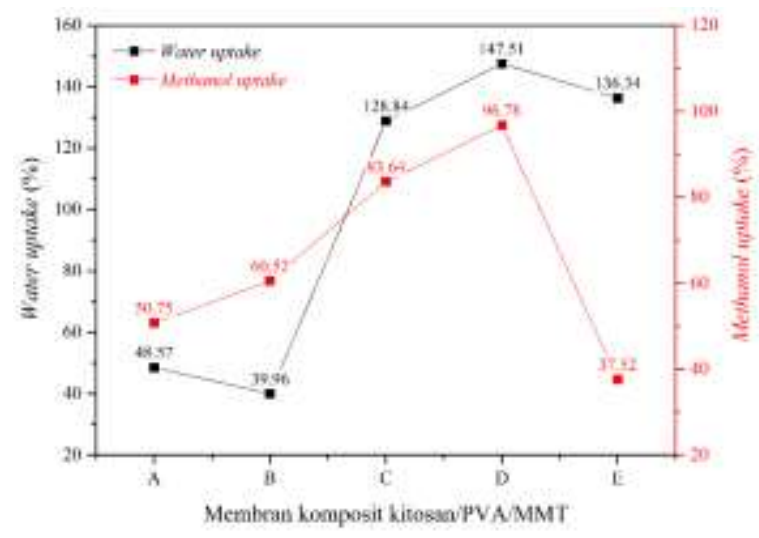

Gambar 3. Grafik water uptake dan methanol uptake dari membran CS (a), CS/PVA (b), CS/PVA/MMT 1\% (c), 2\% (d), dan 4\% (e) 
Dari Gambar 3 dapat dilihat bahwa membran CS/PVA/MMT 4\% lebih menjanjikan dengan memiliki nilai methanol uptake yang jauh lebih rendah meskipun nilai water uptake lebih rendah sedikit dari membran CS/PVA/MMT 2\%. Membran dengan perbandingan kitosan:PVA (1:3) memiliki nilai water uptake yang sangat tinggi, hal tersebut disebabkan PVA memiliki gugus hidroksil yang mampu menahan banyak molekul air, sehingga bersifat hidrofilik dan diketahui dapat menyerap air hampir menyamai beratnya sendiri. (Safitri, 2016). Membran dengan modifikasi MMT memiliki serapan air lebih tinggi daripada membran tanpa MMT. Selain itu membran dengan konsentrasi MMT yang tinggi memberikan nilai serapan yang lebih tinggi karena sifat hidrofilik filler tanah liat dari montmorillonit (Umar, Permana and Atmaja, 2016).

Membran komposit CS/PVA/MMT $4 \%$ secara keseluruhan lebih baik dibandingkan dengan membran CS murni maupun CS/PVA. Selain itu, membran CS/PVA/MMT $4 \%$ juga lebih baik dibandingkan dengan membran Nafion yang memiliki presentase water uptake sebesar $20 \%$ dan methanol uptake sebesar $70 \%$ (Miyake, Wainright and Savinell, 2001).

\section{Uji Permeabilitas Metanol}

Tabel 4. Nilai permeabilitas metanol membran

\begin{tabular}{|c|c|c|c|}
\hline Membran & $\mathrm{L}(\mathrm{cm})$ & $\begin{array}{c}\mathrm{A} \\
(\mathrm{cm} \\
2\end{array}$ & $\begin{array}{c}\text { Permeabilitas } \\
\left(\mathrm{cm}^{2} \mathrm{~s}^{-1}\right)\end{array}$ \\
\hline CS & 0,01 & 3,14 & $3,184 \times 10^{-6}$ \\
\hline CS/PVA & 0,005 & 3,14 & $1,592 \times 10^{-7}$ \\
\hline $\begin{array}{c}\text { CS/PVA/MMT } \\
1 \%\end{array}$ & 0,005 & 3,14 & $1,114 \times 10^{-7}$ \\
\hline $\begin{array}{c}\text { CS/PVA/MMT } \\
2 \%\end{array}$ & 0,0075 & 3,14 & $4,777 \times 10^{-7}$ \\
\hline $\begin{array}{c}\text { CS/PVA/MMT } \\
4 \%\end{array}$ & 0,0025 & 3,14 & $7,165 \times 10^{-8}$ \\
\hline
\end{tabular}

Untuk mengetahui kinerja membran untuk aplikasi Direct Methanol Fuel Cell
(DMFC) dilakukan uji permeabilitas metanol. Ketika jumlah molekul metanol melewati membran sangat banyak, dapat menyebabkan penurunan voltase, sehingga mengganggu kinerja sel bahan bakar (Miyake, Wainright and Savinell, 2001).

Secara keseluruhan penentuan permeabilitas metanol untuk setiap membran diperoleh berdasarkan kemiringan (slope) pada masing-masing kurva hubungan antara waktu dan konsentrasi metanol yang berhasil melewati membran, seperti pada Gambar 4.

Seperti yang sudah diketahui jika nilai konsentrasi metanol semakin tinggi, maka metanol yang melewati membran juga banyak, sehingga nilai permeabilitas metanolnya tinggi. Tabel 4 memperlihatkan nilai permeabilitas metanol tiap membran.

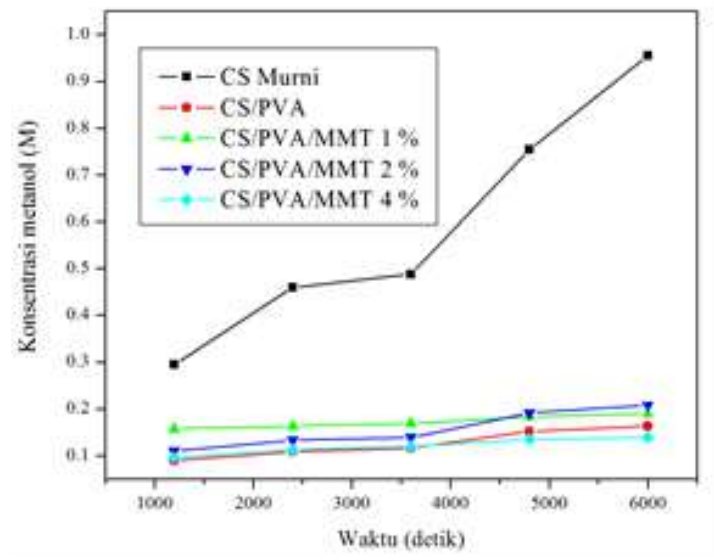

Gambar 4. Kurva hubungan waktu vs konsentrasi metanol yang melewati membran.

Dilihat dari Tabel 4, trend penurunan nilai permeabilitas metanol disebabkan oleh penambahan PVA dan konsentrasi montmorillonit. Penurunan ini disebabkan oleh pendispersian partikel anorganik meningkatkan jumlah jalur berliku (path length and tortuosity) permeasi metanol, sehingga membuat molekul metanol sulit untuk melewati membran.

Secara keseluruhan membran CS/PVA/MMT 4\% sangat menjanjikan sebagai alternatif dalam aplikasi membran untuk Direct Methanol Fuel Cell (DMFC). Yang mana membran ini memiliki nilai 
permeabilitas metanol yang sangat rendah yakni 7,165 x 10-8 jauh lebih lebih kecil daripada membran Nafion- 117 maupun membran kitosan murni (CS).

\section{Simpulan}

Berdasarkan hasil penelitian dan pembahasan yang telah dilakukan, dapat disimpulkan bahwa pengaruh komposisi montmorilonit terhadap perilaku membran komposit Kitosan/PVA/MMT sebagai berikut:

1. Pada analisa FTIR penambahan konsentrasi montmorilonit menyebabkan serapan spektra FTIR semakin tajam pada daerah panjang gelombang $1107 \mathrm{~cm}^{-1}$ yaitu vibrasi gugus fungsi -Si-0 dan 618 $\mathrm{cm}^{-1}$ vibrasi Al-O-Si.

2. Pada analisa water uptake dan methanol uptake secara umum penambahan konsentrasi montmorilonit dapat meningkatkan persentase water uptake dan methanol uptake.

3. Penambahan konsentrasi montmorilonit pada membran komposit dapat menurunkan nilai permeabilitas metanol.

\section{Ucapan Terima Kasih}

Penulis berterima kasih kepada tim penelitian membran kitosan Laboratorium Kimia Material dan Energi Departemen Kimia FMIPA ITS, Pak Lukman Admaja selaku ketua riset serta semua pihak yang ikut membantu.

\section{Daftar Pustaka}

Abu-Saied, M. A. et al. (2020) 'Novel sulphonated poly (vinyl chloride)/poly (2acrylamido-2-methylpropane sulphonic acid) blends-based polyelectrolyte membranes for direct methanol fuel cells', Polymer Testing. Elsevier Ltd, 89(May), p. $106604 . \quad$ doi: 10.1016/j.polymertesting.2020.106604.

Barragán, V. M. et al. (2004) 'Transport of methanol and water through Nafion membranes', Journal of Power Sources, 130(1-2), pp. 22-29. doi: 10.1016/j.jpowsour.2003.12.007.

Enggita, A. P. and Santoso, E. (2015) 'Pengaruh Komposisi terhadap Perilaku Membran', Jurnal Sains dan Seni ITS, 4(2), pp. 1-5.

Gurau, B. and Smotkin, E. S. (2002) 'Methanol crossover in direct methanol fuel cells: A link between power and energy density', Journal of Power Sources, 112(2), pp. 339-352. doi: 10.1016/S0378-7753(02)00445-7.

Junianto, M. (2017) Efek asam sulfosuksinat terhadap sifat fisik komposit kitosan/montmorillonit. Skripsi, tidak dipublikasikan. Institut Teknologi Sepuluh Nopember.

Kakati, N. et al. (2015) 'An approach of balancing the ionic conductivity and mechanical properties of PVA based nanocomposite membrane for DMFC by various crosslinking agents with ionic liquid', International Journal of Hydrogen Energy. Elsevier Ltd, 40(22), pp. 7114-7123. Available at: http://dx.doi.org/10.1016/j.ijhydene.2015.0 4.004 .

Khan, T. A., Peh, K. K. and Ch'ng, H. S. (2002) 'Reporting degree of deacetylation values of chitosan: The influence of analytical methods', Journal of Pharmacy and Pharmaceutical Sciences, 5(3), pp. 205-212.

Lavorgna, M. et al. (2010) 'Study of the combined effect of both clay and glycerol plasticizer on the properties of chitosan films', Carbohydrate Polymers. doi: 10.1016/j.carbpol.2010.04.054.

Li, L., Xu, L. and Wang, Y. (2003) 'Novel proton conducting composite membranes for direct methanol fuel cell', Materials Letters, 57(8), pp. 1406-1410.

Liu, B. et al. (2011) 'Rapid modification of montmorillonite with novel cationic Gemini surfactants and its adsorption for methyl orange', Materials Chemistry and Physics, 
130(3), pp. 1220-1226.

Liu, Hai et al. (2016) 'Chitosan/silica coated carbon nanotubes composite proton exchange membranes for fuel cell applications', Carbohydrate Polymers. Elsevier Ltd., 136, pp. 1379-1385. doi: 10.1016/j.carbpol.2015.09.085.

Liu, X. W., Hu, M. and Hu, Y. H. (2008) 'Chemical composition and surface charge properties of montmorillonite', Journal of Central South University of Technology (English Edition). doi: 10.1007/s11771-0080037-4.

Ma, J. and Sahai, Y. (2013) 'Chitosan biopolymer for fuel cell applications', Carbohydrate Polymers. Elsevier Ltd., 92(2), pp. 955-975.

doi: 10.1016/j.carbpol.2012.10.015.

Miyake, N., Wainright, J. S. and Savinell, R. F. (2001) 'Evaluation of a Sol-Gel Derived Nafion/Silica Hybrid Membrane for Polymer Electrolyte Membrane Fuel Cell Applications: II. Methanol Uptake and Methanol Permeability', Journal of The Electrochemical Society, 148(8), p. A905.

Purwanto, M. et al. (2016) 'Biopolymerbased electrolyte membranes from chitosan incorporated with montmorillonitecrosslinked GPTMS for direct methanol fuel cells', RSC Advances. Royal Society of Chemistry, 6(3), pp. 2314-2322. Available at: http://dx.doi.org/10.1039/C5RA22420A.

Ren, X. (1995) 'Methanol Cross-over in Direct Methanol Fuel Cells', ECS Proceedings Volumes, 1995-23(1), pp. 284-298. doi: $10.1149 / 199523.0284 \mathrm{pv}$.

Safitri, G. (2016). Pengaruh variasi komposisi PVA/Kitosan terhadap perilaku membran komposit PVA/Kitosan/Grafin Oksida yang terikat silang Trisodium Sitrat. Skripsi, tidak dipublikasikan. Institut Teknologi Sepuluh Nopember

Smitha, B., Sridhar, S. and Khan, A. A. (2005) 'Synthesis and characterization of poly(vinyl alcohol)-based membranes for direct methanol fuel cell', Journal of Applied Polymer Science, 95(5), pp. 1154-1163.

Tripathi, B. P. and Shahi, V. K. (2011) 'Organic-inorganic nanocomposite polymer electrolyte membranes for fuel cell applications', Progress in Polymer Science (Oxford). Elsevier Ltd, 36(7), pp. 945-979. Available at: http://dx.doi.org/10.1016/j.progpolymsci.2 010.12.005.

Umar, S., Permana, D. and Atmaja, L. (2016) 'Effect of Glutaraldehyde Concentration Variation toward Properties and Performance of Composite Membrane (ChiMmt) for DMFC Application', 2(1), pp. 199200.

Vaghari, H. et al. (2013) 'Recent advances in application of chitosan in fuel cells', Sustainable Chemical Processes. doi: 10.1186/2043-7129-1-16.

Zhu, J. et al. (2015) 'Fabrication of a novel "loose" nanofiltration membrane by facile blending with Chitosan-Montmorillonite nanosheets for dyes purification', Chemical Engineering Journal. Elsevier B.V., 265, pp. 184-193. Available at: http://dx.doi.org/10.1016/j.cej.2014.12.054. 